\title{
Clinical and biological correlations in acute toxoplasmosis
}

\author{
Andrei Csep \\ From The 10th Edition of the Scientific Days of the National Institute for Infectious Diseases "Prof Dr Matei Bals" \\ Bucharest, Romania. 15-17 October 2014
}

\section{Background}

Toxoplasmosis is a zoonosis caused by a coccidian protozoan, Toxoplasma gondii.

\section{Methods}

The study included 407 non-pregnant women with high risk for toxoplasmosis, presented to the Infectious Diseases Clinic in Oradea in the period 01.01.2009-31.12.2012. By MEIA (Microparticle Enzyme Immunoassay) performed in Bioclinica laboratories, values of Toxoplasma IgM and IgG antibodies were determined and by EIA (Enzyme Immunoassay), the values of IgA Toxoplasma antibodies, as well as the dynamic tracing of their evolution over a period of 12 month.

\section{Results}

The results of investigations showed that $24.3 \%$ of nonpregnant women had acute toxoplasmosis, $25.6 \%$ had acute toxoplasmosis in their past, at a rate of $60 \%$ the serology was completely negative. Most cases of acute toxoplasmosis were diagnosed in spring and autumn $(\mathrm{p}=0.0373)$. The most affected range was the age group 21-25 and 26-30 ( $<<0.0001)$. The gynecologist and the patients' own initiative has an important role in guiding them to make analysis $(\mathrm{p}<0.0001)$. The main reason for presentation to the Infectious Clinic was the appearance of adenopathies with cervical localization $(\mathrm{p}=0.0001)$. The optimum period of time necessary to achieve negative level of IgM and IgA Toxoplasma was between 3 to 6 months after presentation $(\mathrm{p}<0.0001)$.

\section{Conclusion}

The infection with Toxoplasma gondii affects especially young women; most of the cases appear in spring and autumn.

\section{Correspondence: csep.andrei@gmail.com

Faculty of Medicine and Pharmacy, University of Oradea, Romania
Published: 15 October 2014

doi:10.1186/1471-2334-14-S7-P15

Cite this article as: Csep: Clinical and biological correlations in acute toxoplasmosis. BMC Infectious Diseases 2014 14(Suppl 7):P15.
Submit your next manuscript to BioMed Central and take full advantage of:

- Convenient online submission

- Thorough peer review

- No space constraints or color figure charges

- Immediate publication on acceptance

- Inclusion in PubMed, CAS, Scopus and Google Scholar

- Research which is freely available for redistribution
( Biomed Central 